\title{
Insulin-Like Growth Factor-Binding Protein 7
}

National Cancer Institute

\section{Source}

National Cancer Institute. Insulin-Like Growth Factor-Binding Protein 7. NCI Thesaurus. Code C73534.

Insulin-like growth factor-binding protein 7 (282 aa, $29 \mathrm{kDa}$ ) is encoded by the human IGFBP7 gene. This protein may play a role in the sequestration of insulin-like growth factors. 